\title{
THE IMPACT OF THE GLOBAL FINANCIAL CRISIS ON A-REITs
}

\author{
GRAEME NEWELL \\ University of Western Sydney
}

and

\author{
HSU-WEN PENG \\ National Taipei University
}

\section{ABSTRACT}

A-REITs have previously been highly successful indirect property investment vehicles in Australia. However, the global financial crisis has had a significant impact on the performance of A-REITs in 2007-09. This has seen the factors of international property exposure, high debt levels and stapled securities structures having an impact on A-REIT performance. This paper assesses the changing risk profile and portfolio diversification benefits of A-REITs over 1996-2008, specifically identifying the impact of international property, high gearing and property development activities on the performance and risk profile of A-REITs in the current global credit crisis. The impact of high gearing is seen to be the most critical factor in recent A-REIT under-performance.

Keywords: A-REITs, risk profile, global financial crisis, gearing levels, international property, stapled securities

\section{INTRODUCTION}

Over previous years, A-REITs (previously LPTs) have become a mature, sophisticated, highly successful indirect property investment vehicle in Australia. With an outstanding track-record and significant commercial property assets, A-REITs were attractive to both general investors and institutional investors. This saw A-REITs as the second largest REIT market globally, as well as being a key ingredient in Australia being seen as the world's most transparent property market (JLL, 2008).

The success of A-REITs has seen considerable research into specific aspects of A-REITs as property investment vehicles, including:

- performance analysis issues (Lee et al, 2007, 2008; Newell, 2006; Newell and 
Peng, 2006; Newell and Tan, 2003, 2004; Peng, 2004; Tan, 2004a, 2004b; Ratcliffe and Dimovski, 2007)

- IPO/financing issues (Chikolwa, 2007, 2008; Dimovski and Brooks, 2006a, 2006b, 2007)

- $\quad$ investor acceptance (Newell, 2007a, 2007b, 2008)

- fund manager decision-making (Newell and McIntosh, 2007; Newell and Peng, 2008; Tan, 2004c, 2004d),

with much of this A-REIT research highlighting the strong performance, low risk, portfolio diversification benefits and investor acceptance of A-REITs.

However, the traditional rental income-focused A-REIT structure involving prime commercial properties has changed considerably in recent years, as A-REITs have adopted more aggressive growth strategies. These growth strategies have included increased levels of debt, increased levels of international property, the use of stapled securities structure to incorporate property development activities and other fund management activities, and investing in the emerging property sectors (eg: retirement, healthcare, leisure, childcare) (Newell, 2006).

Whilst these A-REIT growth strategies were initially successful (Newell, 2006; Newell and McIntosh, 2007), the global financial crisis has had a significant impact on the performance of A-REITs over 2007-09, as well as highlighting the ongoing potential structural deficiencies of A-REITs as an effective indirect property investment vehicle. As such, this paper examines A-REITs at December 2008 and assesses the changing risk profile and portfolio diversification benefits of A-REITs over 1996-2008; particularly highlighting the last two years and the impact of the global financial crisis on A-REIT performance. The specific impact of the key factors of high gearing, increased international property exposure and stapled securities structure on A-REIT performance will also be assessed.

\section{SIGNIFICANCE OF A-REITs IN 2008}

At September 2007, the A-REIT sector had total assets of over \$207 billion, comprising over 5,000 institutional-grade properties in diversified and sector-specific portfolios (PIR, 2008). This saw A-REITs as the largest institutional owners of commercial property in Australia, significantly ahead of unlisted wholesale property funds. A-REITs accounted for over $\$ 130$ billion in market capitalisation, being one of the largest sectors $(11 \%)$ on the Australian stockmarket. 
A-REITs had delivered consistent strong performance compared to the other major asset classes (see Table 1), being the best performed asset class over 1996-2007 in 67\% of years (8 of 12 years). Sector-specific A-REITs also typically outperformed the corresponding direct property sector over the various holding periods shown in Table 1. A-REITs were also seen to provide some degree of portfolio diversification benefit with shares $(r=0.60$ over 1985-2007), with this diversification benefit having been enhanced in recent years (IPD/PCA, 2007). Globally, this saw A-REITs being the second largest REIT market, accounting for $16 \%$ of the global REIT market capitalisation, with eight of the top 50 global REITs being A-REITs (Macquarie Securities, 2009).

Table 1: A-REIT performance analysis: September 2007

\begin{tabular}{lcccc}
\hline Asset class & $\mathbf{1 Y}$ & \multicolumn{2}{c}{ Average annual total return (\%) } & $\mathbf{3 Y}$ \\
\hline Direct property & $17.27 \%(3)$ & $15.72 \%(3)$ & $13.97 \%(3)$ & $12.18 \%(3)$ \\
A-REITs & $\mathbf{2 0 . 1 3 \% ( 2 )}$ & $\mathbf{2 0 . 7 6 \% ( 2 )}$ & $\mathbf{1 9 . 2 9 \% ( 2 )}$ & $\mathbf{1 4 . 6 7 \% ( 1 )}$ \\
Shares & $33.58 \%(1)$ & $26.39 \%(1)$ & $22.45 \%(1)$ & $13.46 \%(2)$ \\
Bonds & $3.12 \%(4)$ & $4.96 \%(4)$ & $5.06 \%(4)$ & $5.59 \%(4)$ \\
\hline
\end{tabular}

Source: Authors' compilation from IPD/PCA (2007)

However, the global financial crisis has had a major impact on A-REITs, both in terms of stockmarket volatility and concerns over the structure of A-REITs. At December 2008, the A-REIT market capitalisation had reduced to $\$ 52$ billion (UBS, 2009). Table 2 clearly shows the poor performance of A-REITs in 2008, reflecting significant underperformance compared to the highly volatile stockmarket over this period. This poor performance was also evident in each of the A-REIT sub-sectors (see Table 3). At an individual A-REIT level, only one of the 44 A-REITs delivered a positive return in 2008 (Challenger Wine Trust), with a number of major A-REITs significantly underperforming the A-REIT average return for 2008 (eg: GPT, Mirvac, Goodman).

Table 2: A-REIT performance analysis: December 2008

Asset class

Average annual total return (\%)

\begin{tabular}{llcl} 
& $\mathbf{1 Y}$ & $\mathbf{3 Y}$ & $\mathbf{5 Y}$ \\
\hline A-REITs & $-55.3 \%(3)$ & $-18.1 \%(3)$ & $-3.9 \%(3)$ \\
Property & $-69.0 \%(4)$ & $-24.7 \%(4)$ & $-7.7 \%(4)$ \\
companies & & & \\
Shares & $-38.9 \%(2)$ & $-4.0 \%(2)$ & $6.7 \%(2)$ \\
Bonds & $19.1 \%(1)$ & $8.2 \%(1)$ & $7.4 \%(1)$ \\
\hline
\end{tabular}

Source: Authors' compilation from UBS (2009) 
A-REIT type

\begin{tabular}{lccc} 
& $\mathbf{1 Y}$ & $\mathbf{3 Y}$ & $\mathbf{5 Y}$ \\
\hline A-REITs & $-\mathbf{5 5 . 3 \%}$ & $\mathbf{- 1 8 . 1 \%}$ & $-\mathbf{3 . 9 \%}$ \\
Office & $-56.5 \%$ & $-17.3 \%$ & $-5.5 \%$ \\
Retail & $-39.1 \%$ & $-11.9 \%$ & $2.3 \%$ \\
Industrial & $-83.7 \%$ & $-42.7 \%$ & $-20.6 \%$ \\
Diversified & $-66.0 \%$ & $-22.3 \%$ & $-8.8 \%$ \\
International & $-45.9 \%$ & $-13.3 \%$ & $0.8 \%$ \\
Stapled securities & $-50.0 \%$ & $-14.6 \%$ & $-3.9 \%$ \\
\hline
\end{tabular}

Source: Authors' compilation from UBS (2009)

At a global level, this has seen a significant change in the global stature of A-REITs. 2008 saw A-REITs significantly under-perform most other global REIT markets. In particular, A-REITs gave a total return of $-64.8 \%$ (in US\$), compared to US $(-38.3 \%)$, UK (-59.1\%), France (-36.8\%), Japan (-37.1\%), Hong Kong (-28.5\%), Singapore (-56.1\%) and globally (-45.0\%) (S\&P, 2009). This resulted in Australia being \#17 in performance in 2008 amongst the 20 global REIT markets (Macquarie Securities, 2009). This now sees AREITs only accounting for $10.6 \%$ of the global REIT market, dropping back to being the third largest REIT market globally. In comparison, the US is the largest REIT market (51.5\% of the global REIT market) and France as the second largest REIT market $(11.5 \%$ of the global REIT market), with the REIT market in France only being established in 2003. Whilst Westfield is still the largest global REIT, there were only five A-REITs in the top 50 global REITs at December 2008; namely Westfield (\#1), Stockland (\#16), CFS Retail (\#28), GPT (\#31), and Dexus (\#44) (Macquarie Securities, 2009).

The global financial crisis has also had a significant impact on the ongoing viability of AREITs, resulting from this significant volatility and loss of market capitalisation of AREITs. This has seen A-REITs trading at a significant discount to NTA, after many years of trading at a significant premium. Difficulties in accessing debt financing and refinancing have been evident; particularly with the major debt financing sources via commercial mortgage backed securities (CMBS) and syndicated debt facilities being unavailable or too expensive. This has been compounded by many A-REITs having significant debt expiry schedules over 2009-2010.

With many A-REITs potentially breaching their debt covenants (and possibly forced to sell properties), reducing debt levels has been a top priority for A-REITs. This has seen many A-REITs undertake major capital raisings via private placements and rights issues; 
often at significant discounts, with the resultant diluting of shareholder interests. A-REITs have also significantly downgraded their distribution forecasts for 2009-2010, as well as having seen significant write-downs in the value of their property portfolios in a softening commercial property market.

The institutional investment environment has been further compounded for A-REITs by the "denominator effect" now evident for many superannuation funds. This sees many superannuation funds exceeding their property allocation mandate and unable to undertake additional property investments due to liquidity issues, as well as currently being cautious with any new property investment opportunities.

Given the significant growth strategies of A-REITs in recent years and the impact of the global financial crisis on A-REITs, the following sections will examine this impact on the risk and diversification profile of A-REITs in recent years and the significance of increased debt, increased international property exposure and use of stapled securities in this A-REIT performance; particularly during the global financial crisis.

\section{METHODOLOGY}

To carry out these A-REIT performance analyses, monthly total returns were obtained (UBS, 2009) for the $12 \frac{1}{2}$-year period of July 1996 - November 2008 for the 26 AREITs in the ASX300. To assess the dynamics of the changing risk profile and portfolio diversification benefits of A-REITs, these two investment characteristics were assessed using rolling monthly 3-year time periods. Risk is calculated as the standard deviation of returns over the specified time period. The period defined as characterising the global financial crisis was treated as September 2007 - November 2008.

Risk and portfolio diversification benefits were assessed for the following UBS A-REIT series:

- overall A-REIT sector

- A-REIT sub-sectors: office, retail, industrial, diversified, international, stapled securities,

as well as for the stockmarket (All Ordinaries) and bonds (All Maturities).

In addition, three new A-REIT series were developed to assess the impact of specific factors regarding the global financial crisis. This involved the following factors:

- impact of gearing: three sub-series developed low gearing: gearing level below average Nov. 2008 gearing of $33.9 \%$; comprised 7 A-REITs 
(ii) medium gearing: gearing level up to 50\%; comprised 11 A-REITs

(iii) high gearing: gearing level above 50\%; comprised 8 A-REITs

- impact of international property: four sub-series developed

(i) $\quad 100 \%$ domestic portfolio: comprised 6 A-REITs

(ii) merged portfolio $(<50 \%$ international): comprised $10 \mathrm{~A}$-REITs

(iii) merged portfolio ( $>50 \%$ international): comprised 5 A-REITs

(iv) $\quad 100 \%$ international portfolio: comprised 5 A-REITs

- impact of management structure: two sub-series developed

(i) traditional external manager: comprised 3 A-REITs

(ii) stapled securities (internal manager): comprised 23 A-REITs.

Direct property was not included in this A-REIT performance analysis, as the IPD/PCA Australian direct property series is only available quarterly. This would have resulted in too small a data series to rigorously assess the impact of the global financial crisis.

\section{A-REIT RISK DYNAMICS}

Figure 1 presents the A-REIT annual risk profile over 1996-2008, with Figure 2 presenting the equivalent stockmarket annual risk profile. The strong defensive characteristics of A-REITs prior to 2007 are clearly evident, with A-REIT risk being below stockmarket risk in an environment that has seen both A-REITs and stocks reduce their risk profile prior to 2007. Marginal increases in A-REIT risk had occurred since February 2003, which coincided with the increasing levels of gearing, international property and stapled securities by A-REITs. At this stage, prior to 2007, these increases in A-REIT risk were marginal and reflected the effectiveness of A-REIT risk management strategies (Newell, 2006).

Figure 1: A-REIT risk profile: 1996-2008

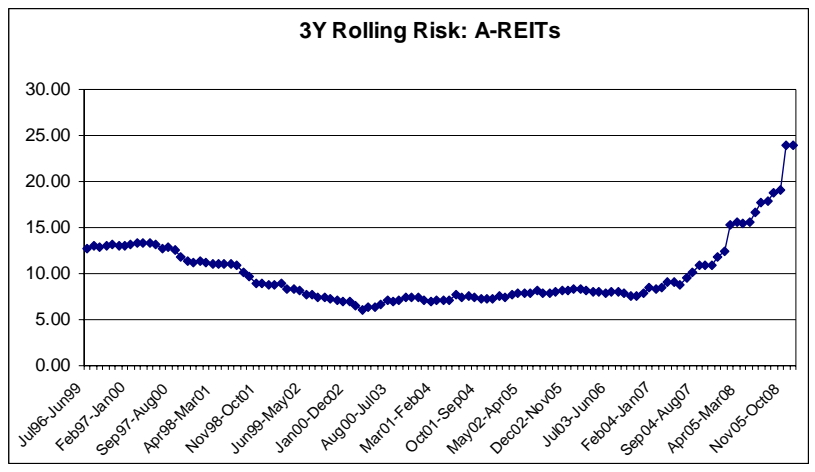


The impact of the global financial crisis on A-REITs is now clearly evident. Since September 2007, A-REIT risk has increased from $10.87 \%$ to $23.88 \%$ in November 2008. This is an increase of $120 \%$ over this 15 -month period. Over this same period, stockmarket risk increased from $8.81 \%$ to $16.65 \%$; an increase of only $89 \%$. This confirms the extra volatility impact seen by A-REITs compared to the general stockmarket during the global financial crisis.

Figures 1 and 2 also demonstrate the loss of defensive characteristics by A-REITs in the global financial crisis. Whilst A-REIT risk was only $52 \%$ of stockmarket risk in February 2003, this has progressively deteriorated in subsequent time periods. By February 2006, A-REIT risk exceeded stockmarket risk for the first time, increasing to $23 \%$ higher by September 2007. By November 2008, A-REIT risk was 43\% higher than stockmarket risk. Overall, this analysis confirms the increasing risk profile of A-REITs, as well as the loss of low risk benefits by A-REITs relative to the stockmarket during the global financial crisis.

Figure 2: Stockmarket risk profile: 1996-2008

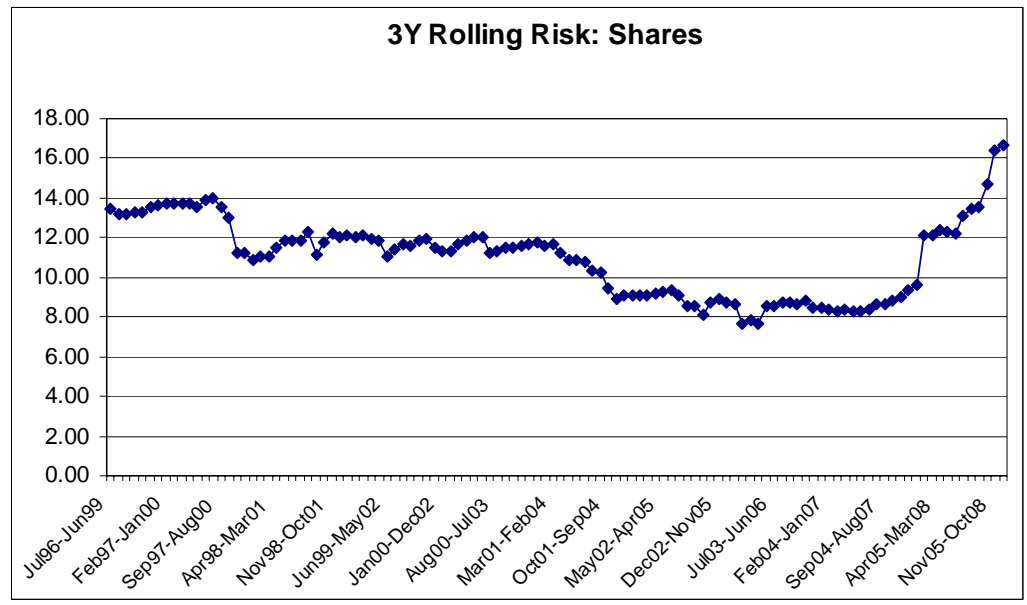


Figure 3: A-REIT sub-sector risk profiles: 1996-2008
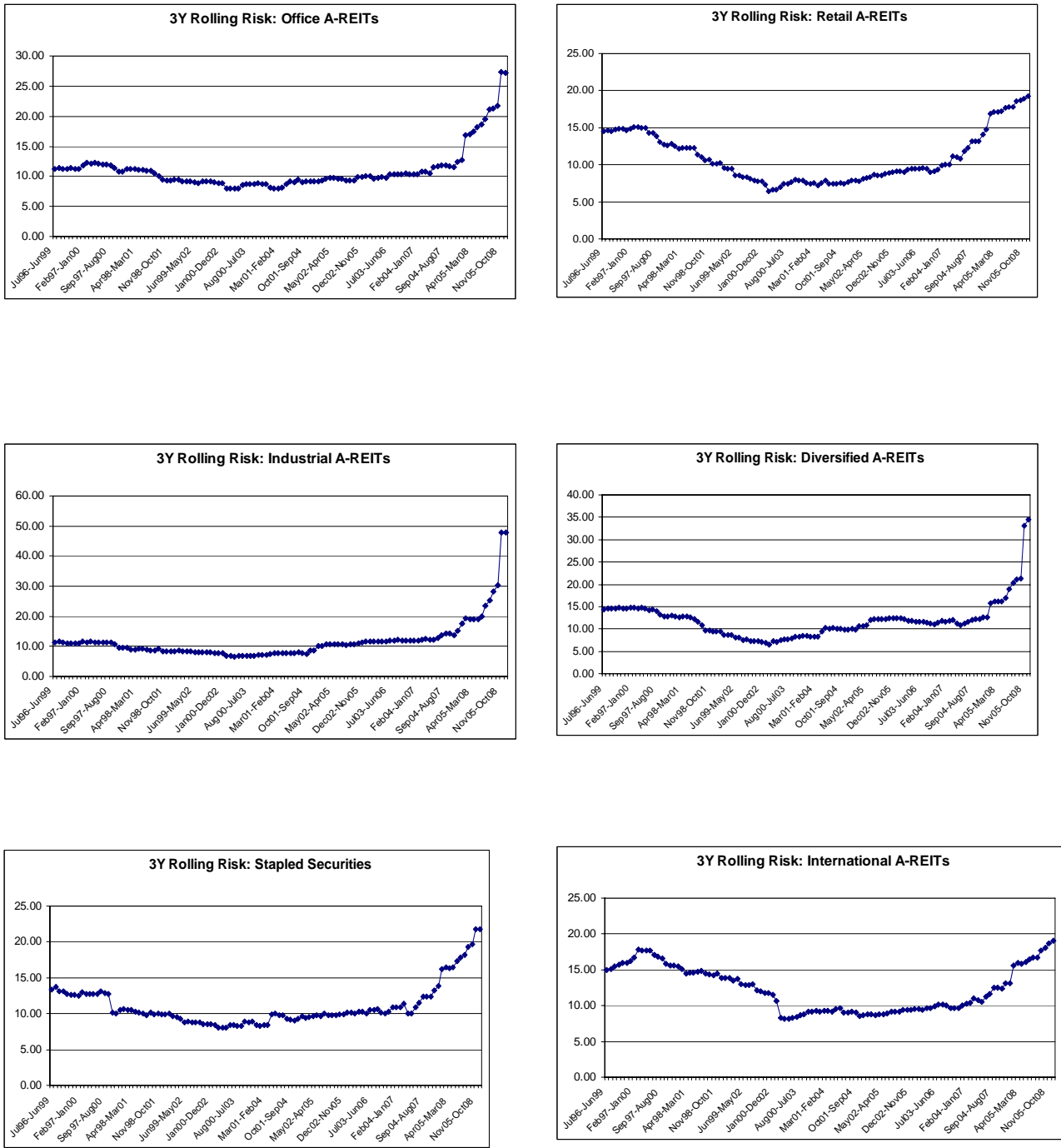
Figure 3 presents the A-REIT sub-sector risk profiles over 1996-2008, with Table 4 summarising the A-REIT sub-sector risk dynamics over the period of the global financial crisis. Whilst all A-REIT sub-sectors experienced significant increases in risk over September 2007 - November 2008, the impact varied across A-REIT sub-sectors. This saw the impact as being most evident for industrial, diversified and office REITs; each being more significant than the $89 \%$ increase in stockmarket risk. This resulted in industrial, diversified and office REIT risk levels in November 2008 being significantly above the general stockmarket risk level; being more than double the stockmarket risk for industrial and diversified REITs. Overall, this analysis confirms the increasing risk profile for all A-REIT sub-sectors, as well as the differing impact across A-REIT sub-sectors regarding loss of low risk benefits relative to the stockmarket during the global financial crisis.

\section{Table 4: Dynamics of A-REIT risk during global financial crisis}

\begin{tabular}{lccccc}
\hline A-REIT sub-sector & $\begin{array}{c}\text { Risk @ } \\
\text { Sept 2007 }\end{array}$ & $\begin{array}{c}\text { Risk @ } \\
\text { Nov 2008 }\end{array}$ & $\begin{array}{c}\text { Increase in } \\
\text { risk }\end{array}$ & $\begin{array}{c}\text { \% ASX risk } \\
\text { @ Sept 2007 }\end{array}$ & $\begin{array}{c}\text { \% ASX risk } \\
@ \text { Nov 2008 }\end{array}$ \\
\hline Office & 11.70 & 27.21 & $133 \%$ & $133 \%$ & $163 \%$ \\
Retail & 13.17 & 19.22 & $46 \%$ & $149 \%$ & $115 \%$ \\
Industrial & 14.28 & 47.85 & $235 \%$ & $162 \%$ & $287 \%$ \\
Diversified & 12.16 & 34.50 & $184 \%$ & $138 \%$ & $207 \%$ \\
International & 12.47 & 19.12 & $53 \%$ & $142 \%$ & $115 \%$ \\
Stapled securities & 12.34 & 21.77 & $76 \%$ & $140 \%$ & $131 \%$ \\
\hline Shares & 8.81 & 16.65 & $89 \%$ & & \\
\hline
\end{tabular}

\section{A-REIT PORTFOLIO DIVERSIFICATION DYNAMICS}

Figure 4 presents the A-REIT correlations with the stockmarket over 1996-2008. Whilst A-REITs enjoyed enhanced portfolio diversification benefits for an extended period prior to 2007, with correlations ranging from $r=0.19$ to $r=0.43$, these correlations have changed significantly since 2007 and specifically since the global financial crisis. This has seen the correlation between A-REITs and the stockmarket increase from $r=0.37$ in September 2007 to $r=0.75$ in November 2008. This clearly reflects a significant loss of portfolio diversification benefits by A-REITs over this 15-month period of the global financial crisis. Whilst this loss of diversification benefit between A-REITs and shares has been evident, this has been offset to some degree by the enhanced diversification benefit between A-REITs and bonds. This has seen the correlation between A-REITs and bonds reducing from $r=0.20$ to $r=-0.13$ over September 2007 - November 2008. Similarly, the correlation between stocks and bonds reduced significantly from $\mathrm{r}=-0.23$ to $\mathrm{r}=-0.55$, reflecting enhanced portfolio diversification benefits between shares and bonds over this Pacific Rim Property Research Journal, Vol 15, No 4, 2009 
15-month period.

Figure 4: A-REIT portfolio diversification: 1996-2008

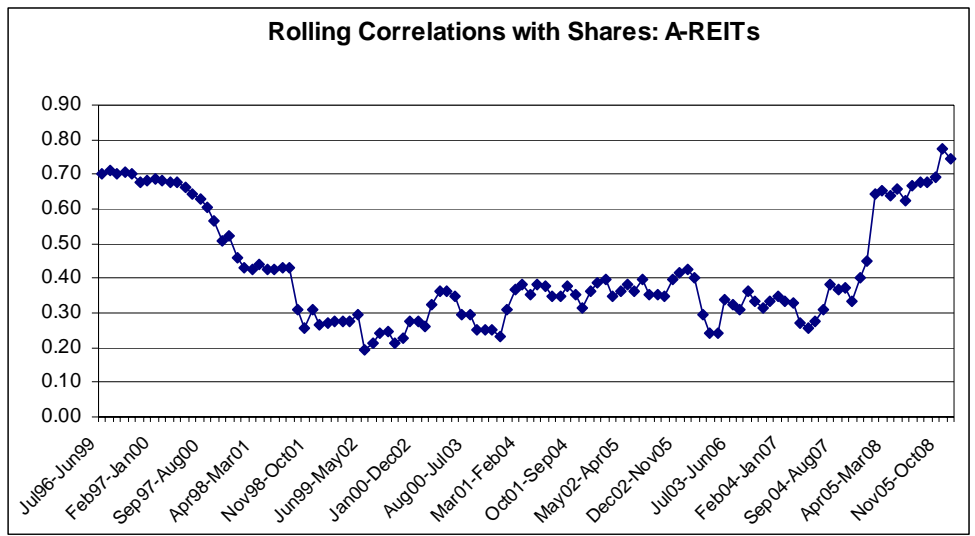

For the various A-REIT sub-sectors, Figure 5 presents the A-REIT sub-sector correlations with the stockmarket over 1996-2008, with Table 5 summarising the A-REIT sub-sector correlation dynamics with the stockmarket over the period of the global financial crisis. All A-REIT sub-sectors showed significant loss of portfolio diversification benefits with the stockmarket over this period, with the impact of loss of diversification benefit generally consistent across the various A-REIT sub-sectors.

This loss of portfolio diversification benefits was also evident within an A-REIT subsector portfolio during the global financial crisis; namely:

- office REIT/retail REIT: $\mathrm{r}=0.45 \rightarrow \mathrm{r}=0.64$

- office REIT/industrial REIT: $r=0.54 \rightarrow \mathrm{r}=0.71$

- retail REIT/industrial REIT: $\mathrm{r}=0.59 \rightarrow \mathrm{r}=0.56$.

Overall, this analysis confirms the loss of portfolio diversification benefits by A-REITs during the global financial crisis, with this loss of diversification benefit being evident across the various A-REIT sub-sectors, as well as within an A-REIT sub-sector portfolio. 
Figure 5: A-REIT sub-sector portfolio diversification: 1996-2008
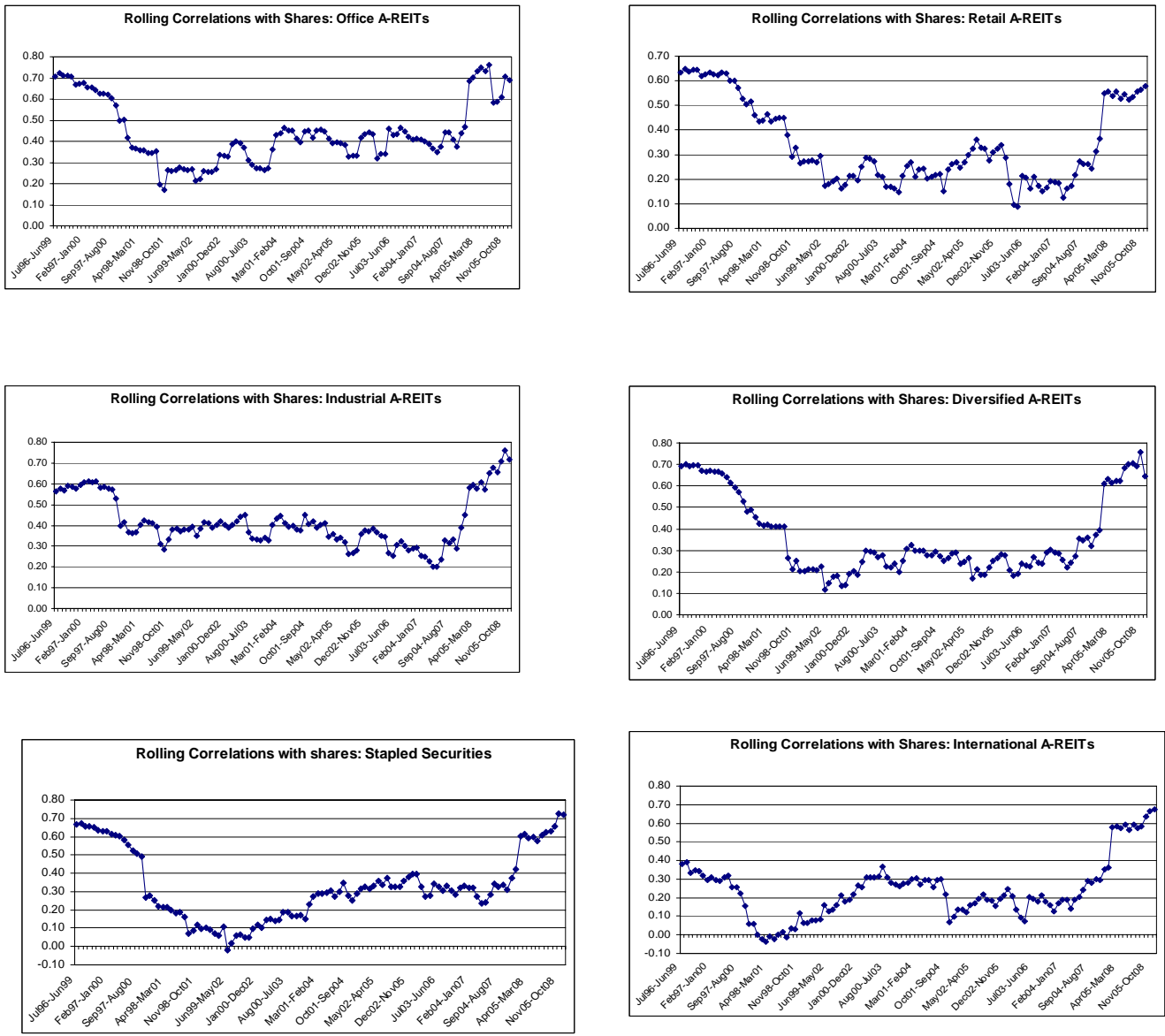
Table 5: Dynamics of the A-REIT sub-sector correlations with the stockmarket during global financial crisis

\begin{tabular}{lccc}
\hline $\begin{array}{l}\text { A-REIT } \\
\text { sub-sector }\end{array}$ & $\begin{array}{c}\text { Correlation @ } \\
\text { Sept 2007 }\end{array}$ & $\begin{array}{c}\text { Correlation @ } \\
\text { Nov 2008 }\end{array}$ & $\begin{array}{c}\text { Increase in } \\
\text { correlation }\end{array}$ \\
\hline Office & 0.41 & 0.69 & +0.28 \\
Retail & 0.26 & 0.58 & +0.32 \\
Industrial & 0.33 & 0.72 & +0.39 \\
Diversified & 0.36 & 0.64 & +0.28 \\
International & 0.30 & 0.68 & +0.38 \\
Stapled securities & 0.34 & 0.72 & +0.38 \\
\hline A-REITs & 0.37 & 0.75 & +0.38 \\
\hline
\end{tabular}

\section{IMPACT OF KEY STRUCTURAL FACTORS}

Key structural factors for A-REITs in recent years have been increased gearing, increased levels of international property and increased use of stapled securities. To assess the impact of these factors during the global financial crisis, new A-REIT series were developed; as discussed previously in the methodology section. Whilst it is not possible to totally isolate the impact of these factors, the following sections present an analysis of the impact of these three structural changes in recent years; particularly highlighting the global financial crisis.

\section{Impact of gearing}

Based on the 26 A-REITs in the ASX300 at November 2008, the impact of gearing on AREITs' returns and risk in 2008 is shown in Figures 7 and 8 respectively. Significant correlations of $r=-0.67$ and $r=0.73$ were seen regarding gearing with returns and risk respectively. 
Figure 6: Within A-REIT sub-sector portfolio diversification: 1996-2008
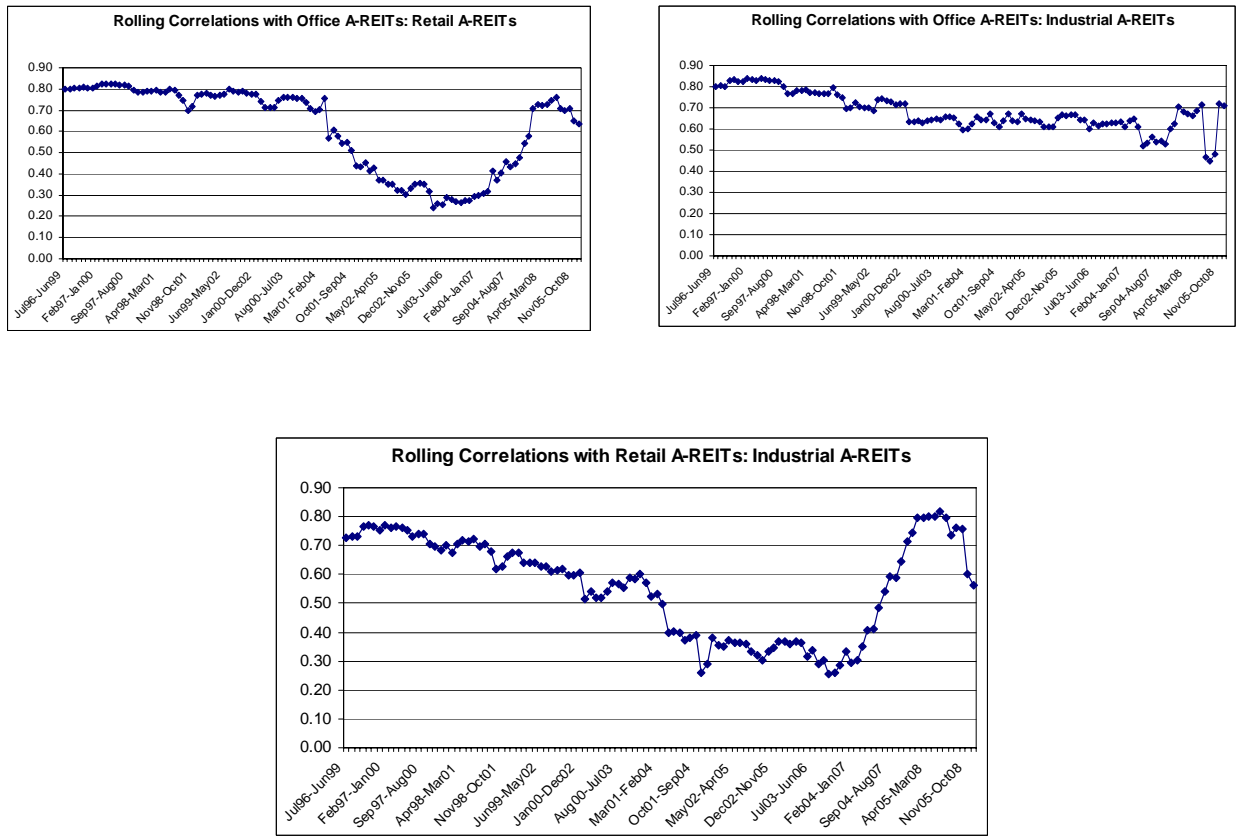

Figure 7: Impact of gearing on A-REIT returns: 2008

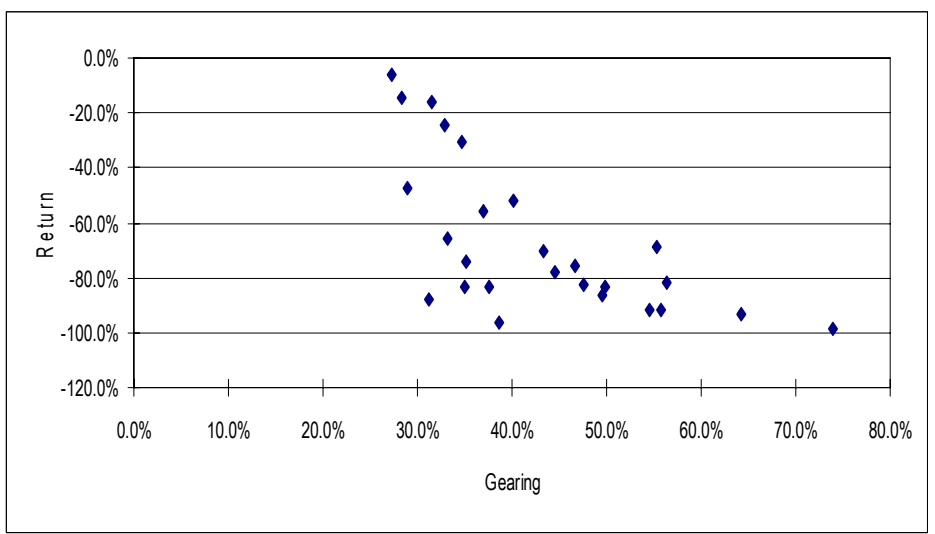

Pacific Rim Property Research Journal, Vol 15, No 4, 2009 
Figure 8: Impact of gearing on A-REIT risk: 2008

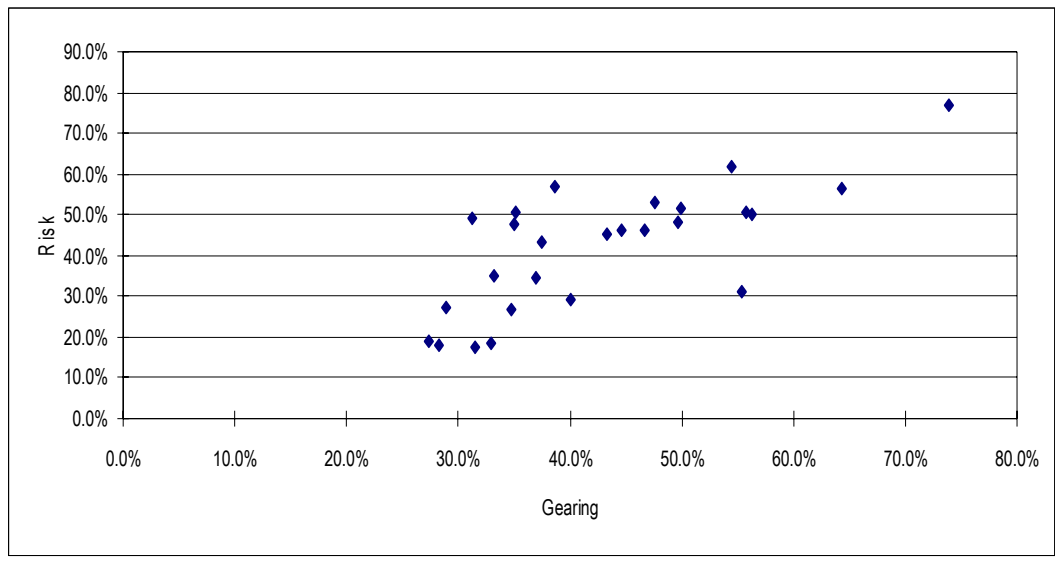

To assess the impact of gearing more fully, Table 6 presents the performance analysis at November 2008 for the three A-REIT gearing levels (ie low, medium and high gearing). The impact of gearing on average returns at 6 months, one year and three years and on annual risk is clearly evident. In each case, low gearing levels delivered a significant improvement in returns at significantly reduced levels of risk. Importantly, for the low gearing scenario, returns out-performed the stockmarket at 6 months and one year, and matched the stockmarket over 3 years. Each of the medium gearing and high gearing series significantly under-performed the stockmarket over each of the three timeframes. This quantitative analysis clearly demonstrates the effectiveness of low gearing in the current global financial crisis. This is in addition to the other qualitative benefits of low gearing in an environment where refinancing of debt is increasingly difficult.

Table 6: Impact of gearing on A-REIT performance: Nov. 2008

\section{Performance}

Gearing level

\begin{tabular}{lcccc} 
& $\mathbf{6 M}$ & $\mathbf{1 Y}$ & $\mathbf{3 Y}$ & Risk \\
\hline Low gearing & $-22.4 \%$ & $-36.9 \%$ & $-4.8 \%$ & $26.3 \%$ \\
Medium gearing & $-60.8 \%$ & $-70.9 \%$ & $-27.9 \%$ & $42.1 \%$ \\
High gearing & $-76.2 \%$ & $-87.0 \%$ & $-51.6 \%$ & $53.3 \%$
\end{tabular}




\section{Impact of international property}

Table 7 presents the performance analysis for the four A-REIT international property series (ie $100 \%$ domestic, merged ( $<50 \%$ international), merged ( $>50 \%$ international) and $100 \%$ international). Whilst the $100 \%$ domestic A-REITs were seen to deliver the best returns, these returns over the various timeframes were poor and significantly underperformed the stockmarket in each instance; particularly during the global financial crisis.

Table 7: Impact of international property on A-REIT performance: Nov. 2008

\begin{tabular}{|c|c|c|c|c|}
\hline \multirow{2}{*}{$\begin{array}{l}\text { Level of } \\
\text { international } \\
\text { property }\end{array}$} & \multicolumn{4}{|c|}{ Performance } \\
\hline & $6 \mathrm{M}$ & $1 Y$ & $3 Y$ & Risk \\
\hline $\begin{array}{l}100 \% \\
\text { domestic } \\
\text { portfolio }\end{array}$ & $-30.8 \%$ & $-43.6 \%$ & $-11.6 \%$ & $29.7 \%$ \\
\hline $\begin{array}{l}\text { Merged } \\
\text { portfolio } \\
(<50 \% \text { Int.) }\end{array}$ & $-56.4 \%$ & $-67.6 \%$ & $-23.9 \%$ & $40.5 \%$ \\
\hline $\begin{array}{l}\text { Merged } \\
\text { portfolio } \\
(>50 \% \text { Int.) }\end{array}$ & $-62.2 \%$ & $-75.2 \%$ & $-42.0 \%$ & $49.9 \%$ \\
\hline $\begin{array}{l}100 \% \\
\text { international } \\
\text { portfolio }\end{array}$ & $-75.0 \%$ & $-84.1 \%$ & $-46.9 \%$ & $48.3 \%$ \\
\hline
\end{tabular}

\section{Impact of stapled securities}

The impact of external management structure versus internal management structure (via stapled securities) on the performance analysis of A-REITs is shown in Table 8. External management structure clearly out-performed the internal management structure over each timeframe at a significantly lower risk level. Importantly, the external manager A-REIT series out-performed the stockmarket in each timeframe; particularly during the global financial crisis. It should be noted that the three A-REITs in this external manager series were also characterised by low gearing and no international property in their portfolios, with some degree of overlap therefore evident between these key factors and demonstrated performance. 
Table 8: Impact of management structure on A-REIT performance: Nov. 2008 Type of management structure 6M $1 Y$ 3Y Risk

\begin{tabular}{lllll}
\hline External manager & $1.4 \%$ & $-11.7 \%$ & $6.1 \%$ & $18.2 \%$
\end{tabular}

Stapled securities $-62.6 \%$

$-73.9 \%$

$-33.5 \%$

$44.3 \%$

(internal manager)

\section{A-REIT IMPLICATIONS}

Along with most REIT markets globally, A-REITs have clearly been impacted by the global financial crisis, both in a local and international context. This paper has clearly demonstrated this impact via under-performance, increased risk and loss of portfolio diversification benefits by A-REITs during the global financial crisis; as well as the impact of key structural factors on A-REIT performance during the global financial crisis.

The issues faced by A-REITs have continued beyond the November 2008 timeframe of this paper. Reducing debt levels continues to be the priority for A-REITs, with further successful capital raisings by several A-REITs; these capital raisings also potentially providing funds for future buying opportunities. Most A-REITs have refocused on their core activities, seeking to dispose of non-core activity properties, as well as focusing on asset enhancement and retaining quality tenants in an increasingly difficult economic environment. However, continued under-performance by A-REITs has been evident in the period post-November 2008; for example, for the six months to May 2009, A-REITs delivered a total return of $-24.7 \%$ compared to the overall stockmarket of $6.5 \%$. This sees A-REITs as the second worst-performing REIT market amongst the 20 global REIT markets. This further highlights the issue of recent A-REIT under-performance reflecting both cyclic and structural issues, with both key issues needing to be effectively resolved for ongoing successful market performance and investor acceptance of A-REITs.

Fortunately, recent months have seen some degree of recovery by the A-REIT sector off this low market cap base. For Q3: 2009, A-REITs gave a total return of 42.6\%; being amongst the best performing REIT markets globally (eg: US(34.5\%), France (45.3\%), UK(26.9\%), Singapore(34.1\%) and Japan(10.8\%)) (S\&P, 2009). This has seen A-REITs return to being the second largest global REIT market at Q3: 2009 (Macquarie Securities, 2009). Further recovery and emergence from the GFC are expected to see A-REITs continue to play a significant role as a leading property investment vehicle in Australia and globally. 


\section{REFERENCES}

Chikolwa, B. (2007), The development of commercial mortgage backed securities in Australia. Pacific Rim Property Research Journal, 13: 397-422.

Chikolwa, B. (2008), Determinants of Australian LPT bond ratings. Pacific Rim Property Research Journal, 14(2): 123-149.

Dimovski, W. and Brooks, R. (2006a), The pricing of property trust IPOs in Australia. Journal of Real Estate Finance and Economics, 32: 185-198.

Dimovski, W. and Brooks, R. (2006b), Factors influencing money left on the table by property trust IPO issuers. Journal of Property Research, 23: 269-280.

Dimovski, W. and Brooks, R. (2007), Factors influencing the direct costs of property trust IPOs. Pacific Rim Property Research Journal, 13(1): 2-15.

Investment Property Databank/Property Council of Australia (2007), Investment Performance Index: September 2007. IPD/PCA, Melbourne.

Investment Property Databank/Property Council of Australia (2009), Investment Performance Index: December 2008. IPD/PCA, Melbourne.

Jones Lang LaSalle (2008), Real Estate Transparency Index. JLL.

Lee, C. L., Reed, R. and Robinson, J. (2007), Momentum profits in Australian listed property trusts. Pacific Rim Property Research Journal, 13(3): 322-343.

Lee, C. L., Robinson, J. and Reed, R. (2008), Downside beta and the cross-section determinants of LPT returns. Journal of Real Estate Portfolio Management, 14(1): 49-62.

Macquarie Securities (2009), Global Property Securities Analytics Monthly Report: September 2009. Macquarie Securities, London (and previous copies).

Newell, G. (2006), The changing risk profile of listed property trusts. Australian Property Journal, 39: 172-180.

Newell, G. (2007a), The significance of property in industry-based superannuation funds. Australian and New Zealand Property Journal, 1: 34-43.

Newell, G. (2007b), The significance of wholesale property funds. Australian and New Zealand Property Journal, 1: 216-233.

Newell, G. (2008), The significance of property in superannuation funds. Australian and New Zealand Property Journal, 1: 670-677. 
Newell, G. and MacIntosh, I. (2007), Currency risk management practices by Australian LPTs. Pacific Rim Property Research Journal, 13: 214-234.

Newell, G. and Peng, H. W. (2006), The significance of emerging property sectors in property portfolios. Pacific Rim Property Research Journal, 12: 177-197.

Newell, G. and Peng, H.W. (2008), LPT fund manager decision-making in the emerging property sectors. Pacific Rim Property Research Journal, 14(2): 222-240.

Newell, G. and Tan, Y.K. (2003), The significance of property sector and geographic diversification in Australian institutional property portfolios. Pacific Rim Property Research Journal, 9: 248-264.

Newell, G. and Tan, Y.K. (2004), The development and performance of listed property trust futures. Pacific Rim Property Research Journal, 10: 132-145.

Peng, V. (2004), Selectivity, timing and the performance of listed property trusts: implications for investment strategies. Pacific Rim Property Research Journal, 10: 235-254.

Property Investment Research. (2008), Property Funds Manager Survey 2008. PIR, Melbourne.

Ratcliffe, C. and Dimovski, W. (2007), The responsiveness of LPT returns and their attributes. Pacific Rim Property Research Journal, 13 (3): 280 - 297.

Standard \& Poor's (2009), Global Property \& REIT Quarterly Report: Q3 2009. S\&P (and previous copies).

Tan, Y.K. (2004a), Benchmarking international property in Australian LPT portfolios. Pacific Rim Property Research Journal, 10: 3-29.

Tan, Y.K. (2004b), The role of international property trusts in Australian mixed-asset portfolios. Pacific Rim Property Research Journal, 10: 215-234.

Tan, Y.K. (2004c), Internal management and size the winning factors. Property Australia, 19(2): 58-59.

Tan, Y.K. (2004d), Is development good for LPTs? Property Australia, 19(3): 50-51.

UBS (2009), UBS Indices: December 2008. UBS.

Email contact: g.newell@uws.edu.au 